\title{
Prevention of Alzheimer's disease: The role of the Mediterranean diet
}

\author{
Prevenção da doença de Alzheimer: o \\ papel da dieta Mediterrânica
}

Maria João SOUSA ${ }^{1}$

Joana GUIMARÃES²

\begin{abstract}
Alzheimer's disease rates have been increasing exponentially and are now considered a $21^{\text {st }}$ century epidemic. It contributes substantially to the morbidity and mortality of older adults. Thus, Alzheimer's disease is a growing major public health concern with a profuse socioeconomic impact. In addition, the existing pharmacological agents only offer modest symptomatic relief and can neither address the progressive neurodegeneration nor cure the disease. Therefore, finding effective preventive and therapeutic measures that delay the onset or reverse the course of the disease is crucial. Several studies have shown that lifestyle factors may play a central role in reducing the risk of developing Alzheimer's disease or, at least, in delaying its clinical symptoms. Among these disease-modifying factors, healthy nutrition has drawn much attention given that it might strongly influence the risk of cognitive decline, dementia, and Alzheimer's disease. Such healthy dietary pattern is the Mediterranean diet. The Mediterranean diet may play a protective role against age-related changes in cognitive function, pre-dementia syndromes, and dementia. Therefore, it may constitute an effective preventive strategy for Alzheimer's disease, with low costs and few side effects. Importantly, these promising preventive measures may translate into strong epidemiological health outcomes, which might lead to a significant progress in public health. An online search was conducted in PubMed in order to revise the literature concerning the association between diet and dementia, specifically, if a higher adherence to the Mediterranean diet pattern is related to lower risk of developing Alzheimer's disease, and to understand the possible mechanisms that may explain such association.
\end{abstract}

Keywords: Alzheimer disease. Diet. Mediterranean diet. Prevention.

\section{R E S U M O}

A doença de Alzheimer tem vindo a aumentar exponencialmente, sendo atualmente considerada uma das epidemias do século XXI e contribuindo significativamente para a morbilidade e mortalidade observadas na

\footnotetext{
1 Universidade do Porto, Faculdade de Medicina. Praceta do Janeleiro, 10, 3515-107, Viseu, Portugal. Correspondência para/Correspondence to: MJ SOUSA. E-mail: <mjmsousa@gmail.com>.

2 Universidade do Porto, Faculdade de Medicina, Serviço de Neurologia e Neurocirurgia do Departamento de Neurociências Clínicas e Saúde Mental. Porto, Portugal.

Artigo elaborado a partir da monografia de MJ SOUSA, intitulada "Prevention of Alzheimer's disease: The role of the Mediterranean diet". Universidade do Porto; 2014-2015.
} 
população idosa. Assim, é um importante problema de saúde pública, com um impacto socioeconômico crescente. Os fármacos usados atualmente apenas contribuem para o alívio sintomático e não atuam no nível do processo neurodegenerativo nem curam a doença. Desse modo, desenvolver medidas preventivas e terapêuticas que sejam eficazes em atrasar ou em reverter o curso da doença é de extrema importância. Vários estudos têm demonstrado que fatores relacionados com o estilo de vida desempenham um papel central em reduzir o risco de desenvolver doença de Alzheimer ou, pelo menos, em atrasar o aparecimento dos sintomas. Um desses fatores é a nutrição, que influencia significativamente o risco de declínio cognitivo, demência e doença de Alzheimer. Um desses padrões dietéticos é a dieta Mediterrânica, que desempenha papel protetor nas alterações da função cognitiva, síndromes pré-demenciais e demência, e, portanto, poderá representar uma estratégia preventiva eficaz para a doença de Alzheimer, com baixos custos e escassos efeitos colaterais. Essas medidas preventivas promissoras poderão resultar em dados epidemiológicos importantes, o que poderá traduzir-se num progresso significativo na saúde pública. Foi efetuada uma pesquisa na PubMed de artigos acerca da associação entre alimentação e demência e, especificamente, acerca da associação entre uma maior adesão à dieta Mediterrânica e o menor risco de desenvolver doença de Alzheimer assim como a verificação de quais os potenciais mecanismos que explicam essa associação.

Palavras-chave: Doença de Alzheimer. Dieta. Dieta mediterrânica. Prevenção de doenças.

\section{INTRODUCTION}

Since its first description in the beginning of the XX century, Alzheimer's disease has gone from a rarely reported disorder to one of the most frequent causes of disability in older adults. Accordingly, cognitive decline and particularly Alzheimer's disease are major contributors to morbidity and mortality worldwide. Numerous studies performed in the last decades have given essential insights into the nature of Alzheimer's disease and importantly, into the magnitude of the problem. However, research on Alzheimer's disease is still an endless challenge, particularly in the area of prevention?

Since the times of Ancient Greece, lifestyle modifications, such as diet and exercise, can recognizably prevent or even treat several diseases, a concept that is well reflected on the well-known Hippocratic saying, "Let food be your medicine, let medicine be your food" (p.1295)². Recently, many efforts have been made to describe the association between diet and cognitive function given that several studies have reported that nutrient intake and dietary practices strongly influence the risk of cognitive decline, dementia, and Alzheimer's disease ${ }^{3}$. In fact, among all the lifestyle factors recently proposed as the first line of protection against the onset and progression of cognitive dysfunction, diet constitutes a promising preventive or even therapeutic approach, as research has shown that certain nutrients and dietary patterns directly interfere with the pathological mechanisms of Alzheimer's disease ${ }^{4,5}$. Such a dietary pattern is the Mediterranean Diet (MeDi), which has been related to increased longevity and lower risk of several chronic diseases, including Alzheimer's disease $^{6}$.

The aim of this paper is to review the literature concerning the association between diet and dementia, specifically, if higher adherence to the MeDi pattern is related to lower risk of developing dementia of the Alzheimer's type, and to understand the mechanisms that may explain such association.

\section{METHODS}

An online search was conducted on PubMed using the query ("Alzheimer disease [MeSH Terms] AND diet"). The inclusion criteria were full-text articles written in English or Portuguese published between 2004 and 2014 that mentioned an association between diet and Alzheimer's disease. The initial exclusion criteria after analyzing titles and abstracts were studies that investigated the role of individual foods/ nutrients on Alzheimer's disease rather than the role of an entire dietary pattern or of the MeDi pattern. 
From the 165 articles obtained initially, 53 were selected after analysis of the titles and abstracts. The final number of references $(n=41)$ was obtained after reading the full texts and conducting a complementary search on "Related citations" and the references of the selected articles (Figure 1).

\section{Alzheimer's disease: The dimension of the problem}

Alzheimer's disease is a neurodegenerative disorder firstly described by Alois Alzheimer in $1907^{7,8}$. Since then, it has been increasing exponentially, and it is now considered a $21^{\text {st }}$ century epidemic, affecting approximately 26 million people worldwide and one quarter of the people aged above 85 years ${ }^{8-11}$.

Alzheimer's disease is the most frequent type of dementia, accounting for more than $75 \%$ of the more than 35 million cases around the world. In developed countries, it is estimated that 1 in 10 individuals over 65, and more than 1 in 3 individuals over 85, suffer from a form of dementia ${ }^{12}$.

According to the World Health Organization, Alzheimer's disease contributes substantially to the morbidity and mortality of older adults ${ }^{13}$. It is clinically characterized by progressive cognitive decline, impairment of activities of daily living, and several

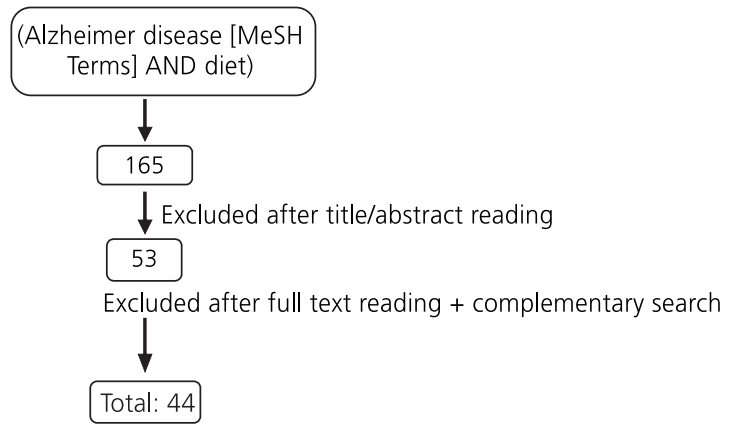

Figure 1. Diagram of the online search and selection of the articles. neuropsychological deformities ${ }^{7}$. In its initial stages, Alzheimer's disease mostly affects shortterm memory (memory of recent events) and language skills, but as it evolves, it progressively affects cognition, function, behavior, and mood $^{14,15}$. In fact, it is the second most common cause of disability, right after depression ${ }^{16}$. Therefore, it is a devastating disease for patients, as it even takes away their sense of self, and also for families, which are strongly affected emotionally, physically, and financially by the rapidly increasing caregiver burden ${ }^{14,15,17}$.

It is estimated that the prevalence of Alzheimer's disease will double every 20 years, foreseeing a total of approximately 115 million people affected by the year of $2050^{12}$. This expected considerable rise may be explained by the growing population aged 65 years or more, as well as by gains in longevity ${ }^{8,16}$. Population aging is extremely relevant given that the incidence of all forms of dementia almost doubles every five years of age ${ }^{18}$. Being already one of the major contributors to health system expenses in many developed countries, this rising incidence will, not surprisingly, be accompanied by a significant increase in direct and indirect costs to society ${ }^{16,18}$. Accordingly, Alzheimer's Disease International predicts an $85 \%$ rise in costs by the year $2030^{14}$.

Overall, Alzheimer's disease is a growing major public health concern with profuse socioeconomic impact ${ }^{19}$.

\section{Alzheimer's disease risk and protective factors}

Although the etiological factors of Alzheimer's disease are still partially unknown, several studies have provided growing evidence for the role of a number of risk and protective factors in the development of the disease ${ }^{12}$. Similarly to other chronic diseases, the development of Alzheimer's disease undoubtedly 
involves a complex interaction of factors, including lifestyle ones, that may start or exacerbate the neurodegenerative process 20,21 .

Old age is the most well-established non-modifiable risk factor, with the number of affected people doubling every four years after the age of $65^{13,22}$. Genetics is another important non-modifiable risk factor: the apolipoprotein-E genotype and mutations in amyloid-precursorprotein, presenilin-1 gene, and presenilin-2 genes $^{23}$.

Modifiable risk factors have also been extensively studied and include low education level, history of depression, head trauma, cerebrovascular disorders, cardiovascular risk factors and diet $^{22,23}$. In fact, these factors exert more influence on the prevalence of Alzheimer's disease than genetics ${ }^{24}$. Proof of this is recent research that showed that older immigrants living in the United States have a higher prevalence of Alzheimer's disease than individuals living in their countries of origin ${ }^{25}$.

These disease-modifying factors have been object of much research in recent years given that interventions that alter their course constitute potential preventive measures ${ }^{19,25}$. Therefore, when motivated and supported by health professionals, individuals can use lifestyle options to influence their late-life cognitive performance and risk of brain disorders ${ }^{10,15,26}$. Among these options, nutrition has drawn much attention as a growing amount of evidence suggests that it may be a key factor in the development of Alzheimer's disease ${ }^{10,24}$.

\section{The importance of Alzheimer's disease prevention}

Given the predicted dramatic rise in the number of Alzheimer's disease patients worldwide, finding effective preventive and therapeutic measures that could delay the onset or reverse the course of the disease is a crucial matter ${ }^{8,18}$.
Currently, the existing pharmacological agents only offer modest symptomatic relief and can neither address progressive neurodegeneration nor cure Alzheimer's disease ${ }^{14,22}$. In fact, research has shown that these agents can slow the progression of some symptoms for only 6 to 12 months, and $50 \%$ of the patients may not respond ${ }^{15}$.

Thus, in the absence of curative strategies, prevention of Alzheimer's disease through risk factor management is essential ${ }^{11,18}$. In fact, it is estimated that delaying the onset of the clinical stage of Alzheimer's disease by 1 and 5 years would decrease its prevalence by 25 and $50 \%$, respectively, after 5 years of implementation of the preventive measures ${ }^{11}$. In addition, while improving clinical outcomes, an efficient preventive strategy would also reduce financial costs and, consequently, lighten the burden of Alzheimer's disease on health care systems ${ }^{13}$.

The most well-established risk factors of Alzheimer's disease, age and the apolipoprotein-E genotype, are not possible targets for prevention ${ }^{4}$. Hence, two of the most promising primary preventive measures would address vascular factors (such as controlling hyper- and hypotension) and lifestyle factors, such as maintaining an active social network, participating in physical and intellectual stimulating activities, and choosing a healthy nutrition pattern ${ }^{12,16}$.

A growing line of evidence suggests that lifestyle factors, particularly diet, may play a central role in managing the illness ${ }^{8}$. Intervention in these areas may reduce the risk of developing Alzheimer's disease or at least delay its clinical symptoms ${ }^{12}$.

Early intervention in the preclinical and prodromal stages of the disease, before the development of clinical symptoms, is of utmost importance ${ }^{5}$. Intervention in these stages would delay the development of Mild Cognitive Impairment $(\mathrm{MCl})$, a transitional and potentially reversible stage between normal aging and 
dementia or Alzheimer's disease, or even reverse $\mathrm{MCl}$ to normal cognitive function, preventing or delaying its progression to dementia ${ }^{4,27}$. Between 6 and $25 \%$ of patients with $\mathrm{MCl}$ convert to Alzheimer's disease every year, making $\mathrm{MCl}$ an appealing stage for preventive interventions ${ }^{7,27}$.

\section{The role of diet on Alzheimer's disease}

In recent years several studies have shown the benefits of healthy nutrition on several chronic diseases, such as cardiovascular disease, cancer, Parkinson's disease, and diabetes ${ }^{11,28}$. Hence, since diet constitutes one of the most important modifiable environmental factors, there has been increasing interest on the potential beneficial role of diet also on Alzheimer's disease ${ }^{19,29}$. As an example, some dietary factors, such as antioxidants, have been reported to reduce the risk of Alzheimer's disease, contrasting with other components, such as saturated fatty acids ${ }^{19}$.

However, foods are not consumed individually but as part of a whole daily diet; in fact, the concept of "dietary pattern" has gained much attention lately regarding several diseases given that it takes into consideration the interactions between the components of a diet, consequently, better reflecting its complexity ${ }^{19,28-30}$. Furthermore, current studies about the role of individual foods on the risk of Alzheimer's disease have presented inconsistent results, partly because people eat meals combining different nutrients or food items that probably have additive and/or synergistic effects $^{6,21}$. Therefore, defining diet by dietary patterns has the ability to capture its multidimensionality and may certainly be more enlightening to the understanding of the effect of nutrition on Alzheimer's disease, and also on other chronic diseases ${ }^{28,30}$.

\section{The Mediterranean diet pattern}

In 2013 the traditional MeDi was recognised as an Intangible Cultural Heritage of
Humanity by the United Nations Educational Scientific and Cultural Organization ${ }^{21}$.

The Mediterranean diet is difficult to define due to some differences in eating and drinking habits between Mediterranean countries $^{13}$. Nevertheless, the most well-known version was presented in the 1990s by Dr. Walter Willet of Harvard University's School of Public Health, and a scientific consensus has been achieved $^{13,14}$. Thus, the traditional MeDi consists of high intake of plant-based foods (fruit as the typical daily dessert, vegetables, legumes, breads, and other types of grains and nuts), olive oil as the major source of monounsaturated fatty acids (used in cooking and salad dressing), low intake of saturated fat, moderately high intake of fish, depending on proximity to the sea, as a source of omega-3 Polyunsaturated Fatty Acids (PUFA), low to moderate intake of dairy products (mostly cheese and yogurt), low to moderate intake of poultry, regular low to moderate intake of wine (normally during meals), low intake of red meat, and a maximum of four eggs weekly,6,14,25,31.

\section{Evidence of the benefits of the Mediterranean diet on cognitive status and Alzheimer's disease}

The benefits of the MeDi pattern were described for the first time by Keys et al. ${ }^{32}$ in the Seven Countries Study in the 1950s and 1960s. They realised that countries in southern Europe presented one of the highest life expectancies in the world, and the rates of several nutritionrelated chronic diseases were among the lowest. Thus, the authors hypothesised that this optimal health status could be linked to their traditional $\operatorname{diet}^{4,21}$.

Since then, an increasing line of evidence has emerged for the protective effects of the MeDi in several chronic diseases, as well as in overall mortality, being now considered one of the healthiest dietary patterns worldwide 21,33 . Accordingly, a meta-analysis showed that 
adherence to the MeDi is associated with important improvement in health status, significantly reducing overall mortality $(9 \%)$, mortality from cardiovascular diseases (9\%), incidence and mortality from cancer $(6 \%)$, and incidence of Parkinson's and Alzheimer's disease $(13 \%)$. These results appear to be clinically significant for public health, especially for including the MeDi pattern in a primary prevention strategy of major age-related chronic diseases $^{14}$.

Several years after the Seven Countries Study, and assuming the concept that what is good for the heart is good for the brain, the Washington Heights-Inwood Columbia Aging Project (WHICAP) was the first study to report a beneficial effect of the MeDi on Alzheimer's disease ${ }^{4,14}$. Scarmeas et al. ${ }^{34}$ concluded that single foods were not significantly associated with risk for Alzheimer's disease, unlike the MeDi pattern: higher adherence to the MeDi was significantly associated with a reduced risk of developing Alzheimer's disease ${ }^{14,35}$. The individuals with medium and high adherence to the MeDi had a 15 to $21 \%$ and a 39 to $40 \%$ reduction in Alzheimer's disease risk, respectively, and each additional unit on the MeDi adherence score reduced the risk of developing Alzheimer's disease by 9 to $10 \%{ }^{34,35}$. These results remained unchanged even after adjustment for several common potential confounders (age, sex, ethnicity, education level, apolipoprotein-E genotype, caloric intake, smoking, comorbidity index, and body mass index), and the gradual risk reduction for higher adherences suggested a dose-response trend ${ }^{34}$.

The Three-City Study, developed in France, showed that higher adherence to the MeDi was significantly associated with better global cognitive function and episodic memory over time $^{14}$.

In 2013 Samieri et al. ${ }^{36}$ suggested that long-term adherence to the MeDi was related to average global cognitive function and verbal memory, a strong early predictor of Alzheimer's disease in older adults, and found that higher adherence delayed cognitive aging by approximately 1 year.

Adherence to the MeDi also reduces the risk of developing $\mathrm{MCl}$ and conversion of $\mathrm{MCl}$ to Alzheimer's disease, suggesting that early intervention may even reduce the risk of developing the prodromal stage of Alzheimer's disease ${ }^{25,27}$. A study from the Mayo Clinic found that higher intake of vegetables and higher unsaturated/saturated fatty acids ratio reduced the risk of $\mathrm{MCl}^{14}$. Another study concluded that for every one-unit rise in participants' MeDi adherence score, the risk of developing $\mathrm{MCl}$ decreased by $8 \%{ }^{3}$.

Furthermore, higher adherence to the MeDi is not only associated with reduced risk of developing Alzheimer's disease but also with lower mortality from Alzheimer's disease ${ }^{28}$. A study showed that individuals with medium and high adherence to the MeDi lived 1.33 and 3.91 years longer, respectively, than those with low adherence $^{37}$.

However, Féart et al. ${ }^{38}$ suggested that there might be a window of opportunity for this beneficial effect to slow cognitive decline and delay the onset of dementia - during the 5 years preceding the clinical diagnosis of dementia, the pathophysiological processes are probably too advanced to be reversed by diet. Therefore, the MeDi would only be effective at least 5 years before the clinical diagnosis of dementia, when Alzheimer's disease pathology and neuronal loss are still limited ${ }^{13,38}$.

Although most studies have been developed in Mediterranean populations, recent research has shown beneficial effects also in nonMediterranean countries ${ }^{39}$. In fact, the WHICAP mentioned above included a multiethnic population of New York ${ }^{34}$. Another study from 2012 Gardener et al..$^{40}$ presented similar findings in an Australian cohort of older adults. Interestingly, given that Australia is a geographically isolated country with a multiethnic population, these similar results strongly support the idea that the 
protective effects of the MeDi are transferable to different populations ${ }^{40}$. Other studies developed in India and in the North of Europe reached the same conclusions ${ }^{34}$.

Chart 1 summarizes the main findings of the selected studies relating the MeDi to Alzheimer's disease.

\section{Biological plausibility}

The beneficial role of the MeDi on agerelated changes in cognitive function, predementia syndromes, and dementia probably occurs through multiple pathways, namely vascular and nonvascular ones ${ }^{11}$. Accordingly, the MeDi is known to reduce the risk of cardiovascular diseases and mortality; therefore, vascular mechanisms could actually be responsible for the protective role of the MeDi on Alzheimer's disease ${ }^{5}$. However, assuming that the MeDi exerts a beneficial effect on cardiovascular disorders and that cardiovascular risk factors are important in Alzheimer's disease, Scarmeas et al. ${ }^{30}$ investigated whether the association between MeDi and Alzheimer's disease was attenuated when vascular risk factors were simultaneously introduced in the statistical model. Surprisingly, these variables did not change the degree of the association, suggesting that it was not mediated by vascular comorbidities ${ }^{4}$. Instead, nonvascular mechanisms, such as inflammation, metabolic disorders, and oxidative stress, may contribute to the association ${ }^{21}$. For example, in the ATTICA study developed in 2004, individuals with the highest adherence to the MeDi had 20 and 17\% lower serum C-Reactive Protein (CRP) and Interleukin-6 (IL-6) serum levels, respectively, and significant reductions in a number of other inflammatory and coagulation markers ${ }^{34}$. In 2010 Gu et al. ${ }^{41}$ performed another study in which they used highsensitivity CRP (hsCRP) as a marker of systemic inflammation and fasting insulin, and adiponectin as markers of metabolic profile. A reduced risk of Alzheimer's disease was observed in individuals with higher adherence to the MeDi, but introducing hsCRP, fasting insulin, or adiponectin in the statistical model did not change the magnitude of the association. These results suggest that higher adherence to the MeDi may reduce Alzheimer's disease risk through noninflammatory or non-metabolic mechanisms or, alternatively, that these biomarkers do not entirely capture these pathways ${ }^{41}$.

The contribution of oxidative stress and also of other important mechanisms will be discussed in detail throughout the next section.

\section{Components of the Mediterranean diet and their mechanisms of action in Alzheimer's disease}

Recent research suggests that the protective effects of the MeDi against cognitive decline in older adults are probably due to the combined effect of a number of foods and nutrients already proposed to play a protective role individually in cognitive impairment or dementia ${ }^{38}$. Some of these foods are described individually in more detail below.

\section{Wine}

The role of moderate consumption of alcohol, especially wine, in neuroprotection is widely recognized ${ }^{42}$.

Moderate intake of wine, particularly during meals, is one of the hallmarks of the $\mathrm{MeDi}^{25}$. An increasing amount of evidence suggests that moderate drinkers (one glass/day for women and two glasses/day for men) have a lower risk of Alzheimer's disease and better cognitive performance than non-drinkers ${ }^{8,25}$. A study developed in Bordeaux (France) showed that mild consumption of wine (1-2 glasses/day) was associated with protection against Alzheimer's disease, while moderate consumption (3-4 glasses/day) conferred additional protection against incident dementia ${ }^{13}$.

The protective effect of daily wine intake remains unchanged at older ages: a study 
Chart 1. Summary of the selected studies on the association between the Mediterranean Diet (MeDi) and risk of Alzheimer's disease.

\begin{tabular}{|c|c|c|c|c|c|c|}
\hline Author/year & Type of study & $\begin{array}{c}\text { Number of } \\
\text { patients }\end{array}$ & Country & Sample & Objective & Main conclusions \\
\hline $\begin{array}{l}\text { Scarmeas } \\
\text { et al., } 2006^{30}\end{array}$ & Case-control & 1984 & $\begin{array}{l}\text { United } \\
\text { States }\end{array}$ & $\begin{array}{c}\text { Multiethnic } \\
\text { population aged } \\
\geq 65 \text { years } \\
\text { (participants of } \\
\text { the WHICAP } \\
\text { study) }\end{array}$ & $\begin{array}{l}\text { To evaluate the } \\
\text { association between } \\
\text { the MeDi and } \\
\text { Alzheimer's disease in } \\
\text { different Alzheimer's } \\
\text { disease populations } \\
\text { and possible vascular } \\
\text { mechanisms. }\end{array}$ & $\begin{array}{l}\text { Higher adherence to the MeDi } \\
\text { was associated with reduced risk } \\
\text { of Alzheimer's disease }(\mathrm{OR}=0.76 \text {; } \\
95 \% \mathrm{Cl}=0.67-0.87 ; \quad p<0.01) \text {. } \\
\text { Introduction of vascular variables } \\
\text { did not affect the magnitude of } \\
\text { the association. }\end{array}$ \\
\hline
\end{tabular}

Scarmeas Prospective 2258 United Multiethnic To evaluate the Higher adherence to the MeDi
et al., $2006^{34}$ cohort States population aged $\geq 65$ years (participants of association between was associated with reduced risk
$M e D i$ the WHICAP Alzheimer's disease. $\quad 95 \% \mathrm{Cl}=0.83-0.98 ; p=0.015$ ). study)

\begin{tabular}{|c|c|c|c|c|}
\hline $\begin{array}{l}\text { Scarmeas } \\
\text { et al., 200737 }\end{array}$ & $\begin{array}{l}\text { Prospective } \\
\text { cohort }\end{array}$ & 192 & $\begin{array}{l}\text { United } \\
\text { States }\end{array}$ & $\begin{array}{c}\text { Multiethnic } \\
\text { population aged } \\
\geq 65 \text { years } \\
\text { (participants of } \\
\text { the WHICAP } \\
\text { study) }\end{array}$ \\
\hline
\end{tabular}

To investigate the Patients with medium and high association between adherence to the MeDi had lower MeDi and mortality in risk of mortality than those with Alzheimer's disease low adherence. patients.

\begin{tabular}{llccc}
\hline $\begin{array}{l}\text { Scarmeas } \\
\text { et al., 200927 }\end{array}$ & $\begin{array}{l}\text { Prospective } \\
\text { cohort }\end{array}$ & 1875 & $\begin{array}{c}\text { United } \\
\text { States }\end{array}$ & $\begin{array}{c}\text { Multiethnic } \\
\text { population aged } \\
\\
\end{array}$ \\
& & & \\
& & (participants of \\
& & the WHICAP \\
& & study)
\end{tabular}

To evaluate the Higher adherence to the MeDi association between was associated with lower risk of $\mathrm{MeDi}$ and $\mathrm{MCl}$ developing $\mathrm{MCl}$ (28\% less risk with the highest adherence; $\mathrm{HR}=0.72 ; 95 \% \mathrm{Cl}=0.52-1.00$; $p=0.05$ ) and lower risk of conversion of $\mathrm{MCl}$ to Alzheimer's disease $(48 \%$ less risk with the highest adherence; $H R=0.52$; $95 \% \mathrm{Cl}=0.30-0.91 ; p=0.02$ ).

\begin{tabular}{llll}
\hline Féart & Prospective & $1410 \quad$ France & $\geq 65$ years \\
et al., 200938 & cohort & &
\end{tabular} To examine the Higher adherence to the MeDi association between was associated with slower MeDi and cognitive cognitive decline evaluated by the performance changes MMSE, but not consistently with and risk for dementia other cognitive tests. However, it in a French cohort of was not associated with risk for older adults. incident dementia.

\begin{tabular}{|c|c|c|c|c|}
\hline $\begin{array}{l}\text { Gu } \\
\text { et al., 201041 }\end{array}$ & $\begin{array}{l}\text { Prospective } \\
\text { cohort }\end{array}$ & 1219 & $\begin{array}{l}\text { United } \\
\text { States }\end{array}$ & $\begin{array}{c}\text { Multiethnic } \\
\text { population aged } \\
\geq 65 \text { years } \\
\text { (participants of } \\
\text { the WHICAP } \\
\text { study) }\end{array}$ \\
\hline
\end{tabular}

To evaluate the Higher adherence to the MeDi association between was associated with lower risk of adherence to the MeDi developing Alzheimer's disease and Alzheimer's disease (34\% less risk with the highest risk and possible adherence). Introduction of inflammatory and inflammatory and metabolic metabolic mechanisms. markers into the statistical model did not change the magnitude of the association.

\begin{tabular}{|c|c|c|c|c|}
\hline $\begin{array}{l}\text { Tangney } \\
\text { et al., } 2011^{42}\end{array}$ & $\begin{array}{l}\text { Prospective } \\
\text { cohort }\end{array}$ & 3790 & $\begin{array}{l}\text { United } \\
\text { States }\end{array}$ & $\begin{array}{l}\geq 65 \text { years } \\
\text { (participants of } \\
\text { the CHAP study) }\end{array}$ \\
\hline
\end{tabular}

To investigate whether Higher MeDi adherence was adherence to the MeDi associated with slower rates of or to the HEl-2005 was cognitive decline, even after associated with adjustment for several variables. cognitive changes in No such association was observed older adults. with the HEI-2005. 
Chart 1. Summary of the selected studies on the association between the Mediterranean Diet (MeDi) and risk of Alzheimer's disease.

\begin{tabular}{|c|c|c|c|c|c|c|}
\hline Author/year & Type of study & $\begin{array}{l}\text { Number of } \\
\text { patients }\end{array}$ & Country & Sample & Objective & Main conclusions \\
\hline $\begin{array}{l}\text { Gardener } \\
\text { et al., } 2012^{40}\end{array}$ & $\begin{array}{l}\text { Cross- } \\
\text { sectional }\end{array}$ & 970 & Australia & $\begin{array}{l}\geq 60 \text { years } \\
\text { (participants of } \\
\text { the AIBL study) }\end{array}$ & $\begin{array}{l}\text { To examine the } \\
\text { association between } \\
\text { adherence to the MeDi } \\
\text { and risk of Alzheimer's } \\
\text { disease and } \mathrm{MCl} \text { in an } \\
\text { Australian cohort of } \\
\text { older adults. }\end{array}$ & $\begin{array}{l}\text { A significant difference was } \\
\text { observed in adherence to the } \\
\text { MeDi between healthy controls } \\
\text { and Alzheimer's disease patients } \\
\text { ( } p<0.001) \text {, and between healthy } \\
\text { controls and MCI patients }(p<0.05) \text {. } \\
\text { MeDi was also associated with } \\
\text { changes on the MMSE score over } \\
18 \text { months }(p<0.05) \text {. }\end{array}$ \\
\hline
\end{tabular}

\begin{tabular}{|c|c|c|c|c|c|}
\hline $\begin{array}{l}\text { Samieri } \\
\text { et al., } 2013^{36}\end{array}$ & $\begin{array}{l}\text { Prospective } \\
\text { cohort }\end{array}$ & 16058 & $\begin{array}{l}\text { United } \\
\text { States }\end{array}$ & $\begin{array}{l}\text { Women aged } \\
\geq 70 \text { years old } \\
\text { (participants of } \\
\text { the NHS study) }\end{array}$ & $\begin{array}{l}\text { To evaluate the Long-term adherence to the MeDi } \\
\text { association between was associated with better } \\
\text { long-term adherence cognition but not with cognitive } \\
\text { to the MeDi and change. } \\
\text { subsequent cognitive } \\
\text { function and decline in } \\
\text { a cohort of older } \\
\text { women. }\end{array}$ \\
\hline
\end{tabular}

Note: HR: Hazard Ratio; 95\%Cl: 95\% Confidence Interval; OR: Odds Ratio; WHICAP: Washington Heights-Inwood Columbia Aging Project; CHAP: Chicago Health and Aging Project; AIBL: Australian Imaging, Biomarkers and Lifestyle; NHS: Nurses' Health Study; MCI: Mild Cognitive Impairment; MMSE: Mini-Mental States Examination; HEl-2005: Healthy Eating Index-2005.

concluded that individuals aged 65 years and above had lower risk of developing Alzheimer's disease when consuming up to three servings of wine a day over 4 years. However, this protective effect was not observed with beer or liquor intake ${ }^{13}$.

The mechanisms through which moderate consumption of wine protects against Alzheimer's disease are still somehow unclear ${ }^{19}$. It may partly be due to alcohol-induced increases in highdensity lipoprotein cholesterol and reductions in fibrinogen and other thrombotic factors, which help preserve brain vessels and prevent subclinical strokes, leading to better cognitive function ${ }^{25}$.

Another possible mechanism is the presence of natural antioxidants in wine, called polyphenols. Polyphenols are the most abundant antioxidants in our diet and are present in high quantities in red wine and olive oil ${ }^{13,19}$. Red wine contains at least 19 types of polyphenols; among these, resveratrol is the most abundant ${ }^{13}$. Thus, the beneficial effect of wine on neurodegeneration can be attributed to resveratrol ${ }^{10}$.

Nevertheless, physicians should be cautious when advising patients about alcohol consumption given that excessive intake causes serious neurologic and other organ damage ${ }^{17}$.

Fish

Several epidemiological studies have suggested that fish intake is associated with a reduced risk of dementia and Alzheimer's disease. In fact, in 2003, Morris et al. ${ }^{43}$ concluded that consumption of fish at least twice a week was associated with $60 \%$ lower risk of developing Alzheimer's disease ${ }^{19}$. Other studies also showed that regular fish intake slows cognitive decline and improves global cognitive function ${ }^{5}$. In the Rotterdam study, Kalmijn et al. ${ }^{44}$ reported that fish intake was not only associated with a reduction in Alzheimer's disease risk but also in all-cause dementia ${ }^{13}$.

The benefits of fish are thought to be due to its high omega-3 PUFA content ${ }^{19}$. Fatty acids are essential components for the central nervous system given that they are neuroprotective, play an important role in brain development, and maintain the structural integrity of neuronal membranes ${ }^{24,25}$. 
Docosahexaenoic Acid (DHA) is an important type of omega-3 PUFA, and its major dietary sources are fish oils and fatty fishes ${ }^{5}$. The brain exhibits high levels of DHA, suggesting that it plays a significant neurophysiological role ${ }^{13}$. In addition, brain levels of DHA tend to drop with age, particularly in Alzheimer's disease patients, and post-mortem analysis of Alzheimer's disease brains reported low levels of omega-3 PUFA in the parahippocampal cortex, features that might contribute to cognitive impairment ${ }^{13,25}$.

Thus, research has described several mechanisms that explain the benefits of fish intake as a major source of omega-3 PUFA. In a study developed in Chicago (IL), specific intake of omega-3 PUFA was associated with a decreased risk of Alzheimer's disease. These fats have beneficial effects on the brain and vascular system, decreasing cerebrovascular and cardiovascular risk factors. Thus, they may limit Alzheimer's disease pathology by reducing amyloid formation, minimizing aggregation into plaques, and increasing its clearance ${ }^{25}$. Omega- 3 PUFA also have anti-inflammatory properties ${ }^{21}$. Ultimately, they possibly have the ability to enhance the activity of endogenous antioxidant enzymes $^{16}$.

\section{Olive oil}

Multiple studies have shown that a diet rich in olive oil is associated with healthier aging and increased longevity ${ }^{13}$.

As mentioned above, olive oil is also rich in antioxidants, such as polyphenols and tocopherols ${ }^{24}$. In a 2010 study, a MeDi high in olive oil was found to reduce the expression of genes related to oxidative stress and inflammatory processes, and to lower plasma levels of lipid oxidation and systemic inflammation markers ${ }^{21}$. Extra virgin olive oil contains tyrosol and caffeic acid, which have been shown to cause significant reductions on IL- 6 production. Olive oil also has the ability to raise levels of enzymes with antioxidant properties ${ }^{30}$. Additionally, polyphenols from olives have been reported to inhibit tau fibrillization. Accordingly, a study developed in 2009 showed that moderate or high use of olive oil resulted in reduced cognitive deficits regarding verbal fluency and visual memory ${ }^{13}$.

Fruits and vegetables

Regular consumption of a medium or large proportion of fruits is associated with a decreased risk of Alzheimer's disease and dementia. Higher vegetable consumption also appears to slow the rate of cognitive decline. These beneficial effects are probably due to their high content of antioxidants and bioactive components (such as polyphenols and vitamins $(\mathrm{C} \text { and } \mathrm{E})^{3,19}$.

Two studies showed that the high levels of polyphenolic components found in fruits, such as blueberries, pomegranates, bananas, oranges and apples, protect against oxidative stress ${ }^{8}$. Tomato products or dishes, such as gazpacho, have also reduced oxidative stress markers, such as isoprostanes ${ }^{24}$.

Two studies have shown the benefits of Concord grape juice and wild blueberry juice. Concord grape juice supplementation for 12 weeks improved verbal learning and recall in individuals with memory decline, and daily intake of wild blueberry juice, also for 12 weeks, by individuals with early memory changes improved paired associate learning and word list recall ${ }^{13}$.

Vitamin $C$ is a strong reducing agent, scavenging several reactive oxygen species. In turn, vitamin $E$, present in high amounts in vegetables, protects cell membranes from oxidation by free radicals. In animal studies, both vitamins showed protection against neuronal death and improved learning and memory. Another study showed that both vitamins were associated with reduced risk of Alzheimer's disease $^{13}$.

CONCLUSION

Despite the global pessimistic scenario around Alzheimer's disease, there are some 
reasons for optimism, given that extensive research has focused in several aspects of the disorder and particularly on early intervention strategies, such as nutritional ones ${ }^{15}$.

The Mediterranean diet has been globally recognized as one of the healthiest dietary models in the world ${ }^{38}$. Its role in brain health translates to slower cognitive decline (particularly the one related to the aging brain), reduced risk of developing $\mathrm{MCl}$, reduced risk of conversion of $\mathrm{MCl}$ to Alzheimer's disease, reduced risk of Alzheimer's disease, and symptomatic relief ${ }^{4,14,25}$. This association is probably mediated by the combined effect of several nutritional components, such as wine, olive oil, fish, fruits, and vegetable ${ }^{25}$.

A specific dietary strategy would represent a totally new approach for the management of Alzheimer's disease. As nutrients are usually welltolerated, such an approach is extremely promising and could exert its effects in synergy with existing and future pharmacological agents ${ }^{9}$.

We believe that further studies are needed, particularly ones that use a more uniform score that could better assess adherence to the MeDi in different countries. However, we also consider that the MeDi, rather than single foods or nutrients, may constitute an effective preventive strategy with low cost, few side effects, and strong epidemiological health outcomes, which may translate to significantly better public health $14,21,37$.

\section{CONTRIBUTORS}

MJ SOUSA participated on the online search, selection of the articles and writing the paper. J GUIMARÃES participated on the online search, writing and revising the article. The final version was approved by both authors.

\section{REFERE N CE S}

1. Daviglus ML, Bell CC, Berrettini W, Bowen PE, Connolly ES, Cox NJ, et al. National Institutes of Health State-of-the-Science Conference Statement:
Preventing Alzheimer's disease and cognitive decline. NIH Consens State Sci Statements. 2010; 27(4):1-30. http://dx.doi.org/10.7326/0003-48 19-153-3-201008030-00260

2. Leonti M. The co-evolutionary perspective of the food-medicine continuum and wild gathered and cultivated vegetables. Genet Res Crop Ev. 2012; 59(7):1295-302. http://dx.doi.org/10.1007/s107 22-012-9894-7

3. Smith PJ, Blumenthal JA. Diet and neurocognition: Review of evidence and methodological considerations. Curr Aging Sci. 2010; 3(1):57-66. http://dx.doi.org/10.2174/187461281100301 0057

4. Féart C, Samieri C, Barberger-Gateau P. Mediterranean diet and cognitive function in older adults. Curr Opin Clin Nutr Metab Care. 2010; 13(1):14-8. http://dx.doi.org/10.1097/MCO.0b0 $13 \mathrm{e} 3283331 \mathrm{fe} 4$

5. Otaegui-Arrazola A, Amiano P, Elbusto A, Urdaneta E, Martínez-Lage P. Diet, cognition, and Alzheimer's disease: Food for thought. Eur J Nutr. 2013; 53(1): 1-23. http://dx.doi.org/10.1007/s00394-013-0 561-3

6. Luchsinger JA, Noble JM, Scarmeas N. Diet and Alzheimer's disease. Curr Neurol Neurosci Rep. 2007; 7(5):366-72. http://dx.doi.org/10.1007/s119 10-007-0057-8

7. Weih M, Wiltfang J, Kornhuber J. Non-pharmacologic prevention of Alzheimer's disease: Nutritional and life-style risk factors. J Neural Transm. 2007; 114(9):1187-97. http://dx.doi.org/10.1007/s00 702-007-0704-x

8. Pasinetti GM, Eberstein JA. Metabolic syndrome and the role of dietary lifestyles in Alzheimer's disease. J Neurochem. 2008; 106(4):1503-14. http://dx.doi. org/10.1111/j.1471-4159.2008.05454.x

9. Scheltens P. Moving forward with nutrition in Alzheimer's disease. Euro J Neurol. 2009; 16(1):19-22. http://dx.doi.org/10.1111/j.1468-1331.2009.027 38.x

10. Ramesh BN, Sathyanarayana Rao TS, Prakasam A, Sambamurti K, Jagannatha Rao KS. Neuronutrition and Alzheimer's disease. J Alzheimer's Dis. 2010; 19(4):1123-39. http://dx. doi.org/10.3233/JAD-20 10-1312

11. Gillette-Guyonnet S, Secher M, Vellas B. Nutrition and neurodegeneration: Epidemiological evidence and challenges for future research. Br J Clin Pharmacol. 2012; 75(3):738-55. http://dx.doi.org/ 10.1111/bcp.12058

12. Povova J, Ambroz P, Bar M, Pavukova V, Sery O, Tomaskova $\mathrm{H}$, et al. Epidemiological of and risk factors for Alzheimer's disease: A review. Biomed 
Papers. 2012; 156(2):108-14. http://dx.doi.org/10. 5507/bp.2012.055

13. Vassallo N, Scerri C. Mediterranean diet and dementia of the Alzheimer type. Curr Aging Sci. 2013; 6(2):150-62. http://dx.doi.org/10.2174/187 4609811306020003

14. Thaipisuttikul P, Galvin JE. Use of medical foods and nutritional approaches in the treatment of Alzheimer's disease. Clin Pract. 2012; 9(2):199-209. http://dx.doi.org/10.2217/cpr.12.3

15. Kidd PM. Alzheimer's disease, amnestic mild cognitive impairment and age-associated memory impairment: Current understanding and progress toward integrative prevention. Altern Med Rev. 2008; 13(2):85-115.

16. Steele M, Stuchbury G, Münch G. The molecular basis of the prevention of Alzheimer's disease through healthy nutrition. Exp Gerontol. 2007; 42(1-2):28-36. http://dx.doi.org/10.1016/j.exger. 2006.06.002

17. Patterson C, Feightner JW, Garcia A, Hsiung G-Y $R$, MacKnight $C$, Sadovnick $A D$, et al. Diagnosis and treatment of dementia: 1. Risk assessment and primary prevention of Alzheimer disease. CMAJ. 2008; 178(5):548-56. http://dx.doi.org/10.1503/ cmaj.070796

18. Middleton L, Yaffe K. Promising strategies for the prevention of dementia. Arch Neurol. 2009; 66(10):1210-5. http://dx.doi.org/10.1001/archneurol. 2009.201

19. Hu N, Yu J-T, Tan L, Wang Y-L, Sun L, Tan L. Nutrition and the risk of Alzheimer's disease. Biomed Res Int. 2013; 2013:524820 http://dx.doi.org/10.1155/ 2013/524820

20. Gustaw-Rothenberg K. Dietary patterns associated with Alzheimer's disease: Population based study. Int J Environ Res Public Health. 2009; 6(4):1335-40. http://dx.doi.org/10.3390/ijerph6041335

21. Féart C, Samieri C, Allès B, Barberger-Gateau P. Potential benefits of adherence to the Mediterranean diet on cognitive health. Proc Nutr Soc. 2013; 72(1):140-52. http://dx.doi.org/10.10 17/S0029665112002959

22. Morris MC. The role of nutrition in Alzheimer's disease: Epidemiological evidence. Eur J Neurol. 2009; 16(1):1-7. http://dx.doi.org/10.1111/j.1468-1 331.2009.02735.x

23. Luchsinger JA, Mayeux R. Dietary factors and Alzheimer's disease. Lancet Neurol. 2004; 3(10):579-87. http://dx.doi.org/10.1016/S1474-4 422(04)00878-6

24. Panza F, Solfrizzi V, Colacicco AM, D'Introno A, Capurso C, Torres F, et al. Mediterranean diet and cognitive decline. Public Health Nutr. 2004;
7(7):959-63. http://dx.doi.org/10.1079/PHN2004 561

25. Arab L, Sabbagh MN. Are certain life style habits associated with lower Alzheimer disease: risk? J Alzheimer's Dis. 2010; 20(3):785-94. http://dx.doi. org/10.3233/JAD-2010-091573

26. Norton MC, Dew J, Smith H, Fauth E, Piercy KW, Breitner JCS, et al. Lifestyle Behavior pattern predicts incident dementia and Alzheimer's disease: The Cache County Study. J Am Geriatr Soc. 2012; 60(3):405-12. http://dx.doi.org/10.1111/j.1532-54 15.2011.03860.x

27. Scarmeas N, Stern Y, Mayeux R, Manly J, Schupf N, Luchsinger JA. Mediterranean diet and mild cognitive impairment. Arch Neurol. 2009; 66(2):216-25. http//:dx.doi.org/10.1001/archneurol. 2008.536

28. Eskelinen MH, Ngandu T, Tuomilehto J, Soininen $\mathrm{H}$, Kivipelto M. Midlife healthy-diet index and late-life dementia and Alzheimer's disease. Dement Geriatr Cogn Dis Extra. 2011; 1(1):103-12. http://dx. doi.org/10.1159/000327518

29. Gu Y, Nieves JW, Stern Y, Luchsinger JA, Scarmeas N. Food combination and Alzheimer disease risk: A protective diet. Arch Neur. 2010; 67(6):699-706. http//:dx.doi.org/10.1001/archneurol.2010.84

30. Scarmeas N, Stern Y, Mayeux R, Luchsinger JA. Mediterranean diet, Alzheimer disease, and vascular mediation. Arch Neur. 2006; 63(12):1709-17. http:// dx.doi.org/10.1001/archneur.63.12.noc60109

31. Knopman DS. Mediterranean diet and late-life cognitive impairment: A taste of benefit. JAMA. 2009; 302(6):686-7. http://dx.doi.org/10.1001/jama. 2009.1149

32. Keys A, Menotti A, Karvonen MJ, Aravanis C, Blackburn $\mathrm{H}$, Buzina $\mathrm{R}$, et al. The diet and 15-year death rate in the seven countries study. Am J Epidemiol. 1986; 124(6):903-15.

33. Gu Y, Scarmeas N. Dietary patterns in Alzheimer's disease and cognitive aging. Curr Alzheimer Res. 2011; 8(5):510-9.

34. Scarmeas N, Stern Y, Tang M, Mayeux R, Luchsinger JA. Mediterranean diet and risk for Alzheimer's disease. Ann Neurol. 2006; 59(6):912-21. http://dx. doi.org/10.1002/ana.20854

35. Kawas $\mathrm{CH}$. Diet and the risk for Alzheimer's disease. Ann Neurol. 2006; 59(6):877-9. http://dx.doi.org/ 10.1002/ana.20898

36. Samieri C, Okereke OI, Devore EE, Grodstein F. Long-term adherence to the Mediterranean diet is associated with overall cognitive status, but not cognitive decline, in women. J Nutr. 2013; 143(4): 493-9. http://dx.doi.org/10.3945/jn.112.169896 
37. Scarmeas N, Luchsinger JA, Mayeux R, Stern Y. Mediterranean diet and Alzheimer disease mortality. Neurology. 2007; 69(11):1084-93. http://dx. doi.org/10.1212/01.wnl.0000277320.50685.7c

38. Féart C, Samieri C, Rondeau V, Amieva $H$, Portet $F$, Dartigues J, et al. Adherence to a Mediterranean diet, cognitive decline, and risk of dementia. JAMA. 2009; 302(6):638-8. http://dx.doi.org/10.1001/ jama.2009.1146

39. Donini LM, De Felice MR, Cannella C. Nutritional status determinants and cognition in the elderly. Arch Gerontol Geriatr. 2007; 44(Suppl. 1):143-53. http://dx.doi.org/10.1016/j.archger.2007.01.022

40. Gardener S, Gu Y, Rainey-Smith SR, Keogh JB, Clifton PM, Mathieson SL, et al. Adherence to a Mediterranean diet and Alzheimer's disease risk in an Australian population. Transl Psychiatry. 2012; 2(10):e164. http://dx.doi.org/10.1038/tp.2012.91

41. Gu Y, Luchsinger JA, Stern Y, Scarmeas N. Mediterranean Diet, inflammatory and metabolic biomarkers, and risk of Alzheimer's disease. J
Alzheimer's Dis. 2010; 22(2):483-2. http://dx.doi. org/10.3233/JAD-2010-100897

42. Tangney CC, Kwasny MJ, Li H, Wilson RS, Evans DA, Morris MC. Adherence to a Mediterraneantype dietary pattern and cognitive decline in a community population. Am J Clin Nutr. 2011; 93(3):601-7. http://dx.doi.org/10.3945/ajcn.110.0 07369

43. Morris MC, Evans DA, Bienias JL, Tangney CC, Bennett DA, Wilson RS. Consumption of fish and $\mathrm{n}-3$ fatty acids and risk of incident Alzheimer disease. Arch Neurol. 2003; 60(7):940-946. http://dx. doi.org/10.1001/archneur.60.7.940

44. Kalmijn S, Launer LJ, Ott A, Witteman JC, Hofman A, Breteler MM. Dietary fat intake and the risk of incident dementia in the Rotterdam Study. Ann Neurol. 1997; 42(5):776-82.

Received: January 9, 2015 Final version: August 17, 2015 Approved: August 31, 2015 
